THE ENLIGHTENMENT 


\section{Studies in European History}

General Editor: Richard Overy

Editorial Consultants: John Breuilly

$$
\text { Roy Porter }
$$

\section{PUBLISHED TITLES}

Jeremy Black A Military Revolution? Military Change

and European Society 1550-1800

T. C. W. Blanning The French Revolution:

Aristocrats versus Bourgeois?

John Breuilly The Formation of the First German

Nation-State, 1800-1871

Peter Burke The Renaissance

Michael Dockrill The Cold War 1945-1963

William Doyle The Ancien Regime

Geoffrey Ellis The Napoleonic Empire

Donald A. Filtzer The Khrushchev Era: De-Stalinism and the

Limits of Reform in the USSR, 1953-1964

Mary Fulbrook The Two Germanies, 1945-1990.

R. G. Geary European Labour Politics from 1900 to the Depression

Graeme Gill Stalinism

Henry Kamen Golden Age Spain

Richard Mackenney The City-State 1500-1700: Republican Liberty in an Age of Princely Power

Andrew Porter European Imperialism 1860-1914

Roy Porter The Enlightenment

Roger Price The Revolutions of 1848

James Retallack Germany in the Age of Kaiser Wilhelm II

Geoffrey Scarre Witchcraft and Magic in

16 th and 17th Century Europe

$R$. W. Scribner The German Reformation

Robert Service The Russian Revolution 1900-1927, Second Edition

\section{FORTHCOMING}

R. G. Bonney The Rise of European Absolutism

Brendan Bradshaw The Counter-Reformation

David Cesarani The Holocaust

Hugh Gough The Terror of the French Revolution

John Henry The Scientific Revolution

David Stevenson The First World War

Clive Trebilcock Problems in European Industrialisation

1800-1914 


\section{THE ENLIGHTENMENT}

ROY PORTER

The Wellcome Institute for the History

of Medicine, London

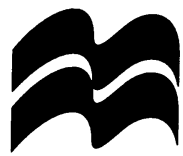


All rights reserved. No reproduction, copy or transmission of this publication may be made without written permission.

No paragraph of this publication may be reproduced, copied or transmitted save with written permission or in accordance with the provisions of the Copyright, Designs and Patents Act 1988, or under the terms of any licence permitting limited copying issued by the Copyright Licensing Agency, 90 Tottenham Court Road, London WIP 9HE.

Any person who does any unauthorised act in relation to this publication may be liable to criminal prosecution and civil claims for damages.

First published 1990 by

\section{MACMILLAN PRESS LTD}

Houndmills, Basingstoke, Hampshire RG21 6XS

and London

Companies and representatives

throughout the world

ISBN 978-0-333-45414-5 ISBN 978-1-349-09885-9 (eBook)

DOI 10.1007/978-1-349-09885-9

A catalogue record for this book is available

from the British Library.

$\begin{array}{rrrrrrrrr}14 & 13 & 12 & 11 & 10 & 9 & 8 & 7 & 6 \\ 03 & 02 & 01 & 00 & 99 & 98 & 97 & 96 & 95\end{array}$

\section{Series Standing Order}

If you would like to receive future titles in this series as they are published, you can make use of our standing order facility. To place a standing order please contact your bookseller or, in case of difficulty,write to us at the address below with your name and address and the name of the series. Please state with which title you wish to begin your standing order. (If you live outside the United Kingdom we may not have the rights for your area, in which case we will forward your order to the publisher concerned.)

Customer Services Department, Macmillan Distribution Ltd Houndmills, Basingstoke, Hampshire RG21 6XS, England 


\section{Contents}

Editor's Preface vii

A Note on References viii

Introduction and Acknowledgements ix

1 What Was the Enlightenment? 1

2 The Goal: a Science of Man 12

3 The Politics of Enlightenment 24

4 Reforming Religion by Reason 32

5 Who Was the Enlightenment? 42

6 Unity or Diversity? 51

7 Enlightenment and Beyond 61

8 Conclusion: Did the Enlightenment Matter? 70

Reading Suggestions $\quad 76$

$\begin{array}{ll}\text { Index } & 89\end{array}$ 


\section{Editor's Preface}

The main purpose of this new series of studies is to make available to teacher and student alike developments in a field of history that has become increasingly specialised with the sheer volume of new research and literature now produced. These studies are designed to present the 'state of the debate' on important themes and episodes in European history since the sixteenth century, presented in a clear and critical way by someone who is closely concerned himself with the debate in question.

The studies are not intended to be read as extended bibliographical essays, though each will contain a detailed guide to further reading which will lead students and the general reader quickly to key publications. Each book carries its own interpretation and conclusions, while locating the discussion firmly in the centre of the current issues as historians see them. It is intended that the series will introduce students to historical approaches which are in some cases very new and which, in the normal course of things, would take many years to filter down into the textbooks and school histories. I hope it will demonstrate some of the excitement historians, like scientists, feel as they work away in the vanguard of their subject.

The format of the series conforms closely with that of the companion volumes of studies in economic and social history which has already established a major reputation since its inception in 1968. Both series have an important contribution to make in publicising what it is that historians are doing and in making history more open and accessible. It is vital for history to communicate if it is to survive.

R. J. OVERY 


\section{A Note on References}

References are cited throughout in square brackets according to the numbering in the Bibliography, with page references where necessary indicated by a colon after the bibliography number. 


\section{Introduction and Acknowledgements}

In the late 1960s there appeared Peter Gay's superb twovolume survey of eighteenth-century thought, The Enlightenment: An Interpretation [42]. In just under a thousand pages of text, Gay, professor of history first at Columbia University and then at Yale, offered a comprehensive investigation of the period, its problems, and its protagonists, written in a lucid and lively style. A further 250 pages of 'Bibliographical Essay' listed and evaluated the massive scholarship already available upon the subject.

Gay wrote, however, at a moment when research into the Enlightenment was beginning to mushroom. In the two decades since his work was published, so many new books and articles have appeared, striking out in a multitude of new directions, and often challenging old truths, that it is doubtful if a comparable enterprise to Gay's could today be contained in fewer than four or five volumes, with a bibliography which would fill another. And who would write it?

Given the vast increase of scholarly attention being lavished on the Enlightenment, it may seem the height of folly to hope to say anything worthwhile in the span of under a hundred pages. But it is important to try. Very few school and college students have easy access to the mountains of new scholarship appearing in monographs and in an ever-increasing number of specialist academic journals covering such diverse fields as literary studies, cultural history, social history, the history of ideas, religion, science, and so forth. Few libraries even possess a complete run of the fundamentally important publications 
of the Voltaire Foundation, whose titles now number around three hundred.

In an introductory pamphlet such as this, there is no room to assess more than a fraction of all this research, or even to list it in the 'Reading Suggestions' at the end of the book. Rather, my approach has been to take the main interpretations and problems respecting the Enlightenment as set out in the leading, readily available accounts produced during the last generation - the works of Gay [42], Hampson [47], Crocker, [30; 31], May [68] and so forth - and to gauge how valid these still remain, or how far, on the contrary, they now require modification. In some fields of study, fresh research has brought to light crucial new information. In others, our perception of what the important questions in the history of thought, ideas and culture really are, has radically changed. This is a point which advocates of Enlightenment would have appreciated: the 'Preliminary Discourse' to Diderot and d'Alembert's celebrated Encyclopédie spoke of the need to create new forms of knowledge to meet the needs of a new world $[60 ; 78]$.

My aims have thus been expository, critical and historiographical; yet I have tried to avoid writing what would essentially be a 'review essay', a mere commentary upon recent scholarship. Instead, I have tried to produce a work which is self-standing and self-contained. Readers will note that rather little is said in the following chapters about the ancien régime as such or about the origins of the French Revolution. This is not because I think they are not germane to the subject. Far from it. But these topics are already fully covered in excellent books appearing in this series, respectively by William Doyle [35] and Tim Blanning [18].

I am most grateful to my fellow editors in this series, Richard Overy and John Breuilly, for their support, encouragement and criticisms in transforming a rough draft into a finished work. Estelle Cohen, Mark Goldie, Margaret Kinnell, Dorothy Porter, Sylvana Tomaselli, Jane Walsh, Andrew Wear and Bob Wolfson have also 
commented upon earlier drafts. Their kindness has saved me from many blunders: my wholehearted thanks to them. Vanessa Graham at Macmillan has been no less patient than supportive. Thanks, as always, to Mrs Jean Runciman for her phenomenal speed and accuracy in compiling the index. 